\title{
Field Resistance to Fire Blight in a Diverse Apple (Malus sp.) Germplasm Collection
}

\author{
James J. Luby \\ Department of Horticultural Science, University of Minnesota, St. Paul, MN 55108
}

Peter A. Alspach

The Horticulture and Food Research Institute of New Zealand, Ltd., Nelson Research Centre, PO Box 220, Motueka, New Zealand

\author{
Vincent G.M. Bus and Nnadozie C. Oraguzie \\ The Horticulture and Food Research Institute of New Zealand, Ltd., Hawkes Bay Research Centre, \\ Private Bag 1401, Havelock North, New Zealand
}

ADDITIONAL INDEX WORDS. Erwinia amylovora, disease resistance, flowering, heritability

\begin{abstract}
Incidence and severity of fire blight [Erwinia amylovora (Burr.) Winslow, Broadhurst, Buchanan, Krumwiede, Rogers, and Smith] following field infection were recorded using families resulting primarily from open-pollination of Malus sylvestris (L.) Mill. var.domestica (Borkh.) Mansf. cultivars and a few other Malus Mill. sp. The families were structured as three sublines, planted in three successive years (1992 to 1994), of a diverse population of apple germplasm established at HortResearch, Hawkes Bay, New Zealand. The incidence of fire blight varied among the sublines with the oldest planting exhibiting more fire blight. Flowering trees were more likely to be infected than nonflowering trees, in terms of both incidence and severity. Furthermore, the level of fire blight was related to flowering date, with later flowering trees having higher levels. Thus, family means and narrow-sense heritability estimates were computed after first adjusting the fire blight score for flowering date by fitting a linear model. Provenance of origin of the maternal parent explained little variation except that $M$. sieversii Lebed. families were more resistant than $M$. sylvestris var. domestica families in one subline. Family means computed using all trees, and those from only flowering trees were highly correlated. Families from open-pollination of $M$. honanensis Rehder and $M$. xhartwiggii Koehne females were among the more susceptible. Those from several European $M$. sylvestris var. domestica cultivars as well as from M. baccata (L.) Borkh. and M. toringoides (Rehder) Hughes females were among the more resistant families. Narrow-sense heritability estimates ranged from 0.05 to 0.85 depending on the subline, with most estimates between 0.12 and 0.36 . They were higher in the two older sublines that consisted primarily of open-pollinated families from $M$. sylvestris var.domestica, and lower in the younger subline that consisted primarily of $M$. sieversii, due to lower incidence and severity in the latter subline. Breeders who consider potential complications of juvenility, tree size, and flowering date in relation to infection periods should be able to exploit field epidemics to perform effective selection.
\end{abstract}

Fire blight, incited by the bacterium Erwinia amylovora, can be a severe disease of apples (Malus spp.) and other species in the family Rosaceae. Erwinia amylovora was apparently indigenous to North America where fire blight was noted in the $18^{\text {th }}$ century. It was transported widely in the $19^{\text {th }}$ and $20^{\text {th }}$ centuries and is now a serious disease in many apple production areas including New Zealand (van der Zwet and Keil, 1979). Resistance to fire blight has become an important objective in several apple breeding programs (Fischer et al., 1983a; Gardner et al., 1980a; Lespinasse and Paulin, 1990; van der Zwet and Keil 1979).

Several researchers reported the relative field resistance of apple cultivars from orchard evaluations in natural epidemics or following controlled inoculation (see van der Zwet and Keil, 1979 for an extensive review of cultivar comparisons and also den Boer and Green, 1995; Bonn and Elfving, 1990; Fischer and Schaefer, 1990; Fischer et al., 1983a; Gardner et al., 1980a; Le Lezec et al., 1987; Thomas and Jones, 1992). The inheritance of fire blight resistance in apple has been studied mainly following inoculation with single or mixed strains of young juvenile seedlings in greenhouses (Aldwinckle and Cummins, 1979; Fischer,

Received for publication 28 Mar. 2001. Accepted for publication 12 Nov. 2001. The authors gratefully acknowledge support from the University of Minnesota and the New Zealand Foundation for Research, Science, and Technology. Madelein Hofstee and Mirco Stefanati assisted with data collection. Dominique Noiton was instrumental in establishing the apple breeding populations. Aimak Djangaliev arranged and assisted in collection of germplasm in Kazakstan.
1996; Fischer et al., 1983b; Gardner et al., 1980b; Korban et al., 1988; Lespinasse and Paulin, 1990;) or older juvenile seedlings in a nursery (Moore, 1946). Researchers have observed quantitative inheritance in most crosses suggesting polygenic control (Fischer et al., 1983b; Gardner et al., 1980b; Korban et al., 1988; Lespinasse and Paulin, 1990; Moore, 1946;). Dominance of resistance has been observed in some crosses (Gardner et al., 1980b; Korban et al., 1988).

At the Horticulture and Food Research Institute of New Zealand, Ltd. (HortResearch), a large apple breeding population has been established to maintain biodiversity for cultivar development (Noiton and Alspach, 1996), as well as to study genetic aspects of important traits (Currie et al., 2000; Noiton and Shelbourne, 1992; Noiton et al., 1999; Oraguzie et al., 2001). The population could potentially provide novel sources of mono- and polygenic resistances to a range of pests and diseases for application in a long-term breeding strategy based on recurrent selection.

This paper reports evaluation of part of the aforementioned population for fire blight damage following natural infection. Due to warm spring weather and abundant inoculum from the previous season, fire blight was common and widespread in the 1998-99 season in the Hawkes Bay production region of New Zealand, including the HortResearch orchards in Havelock North. We were able to 1) assess variation for resistance in this population, 2) identify families and their female parents that were especially resistant or susceptible, and 3) estimate heritability of 
Table 1. Composition of provenances used in the analyses of sublines 92, 93, and 94 and the number of families assigned to each provenance based on species or geographic area of origin of maternal parent of each family.

\begin{tabular}{|c|c|c|c|c|}
\hline \multirow[b]{2}{*}{ Provenance } & \multirow[b]{2}{*}{ Countries included } & \multicolumn{3}{|c|}{ No. families in subline } \\
\hline & & 92 & 93 & 94 \\
\hline \multicolumn{5}{|c|}{ M. sylvestris var. domestica } \\
\hline North America & Canada \& USA & 13 & 6 & 1 \\
\hline United Kingdom & England, Ionian Isles, Scotland & 30 & 9 & 0 \\
\hline Western Europe & $\begin{array}{l}\text { Belgium, Denmark, France, Germany, Italy, Netherlands, } \\
\text { Norway, Sweden, Switzerland }\end{array}$ & 33 & 14 & 11 \\
\hline Eastern Europe & $\begin{array}{l}\text { Czechoslovakia, Belarus, Estonia, Latvia, Lithuania, Moldovia, } \\
\text { Poland, Romania, Russia, Ukraine }\end{array}$ & 22 & 11 & 0 \\
\hline \multicolumn{5}{|l|}{ M. sieversii } \\
\hline M. sieversii 3 & Zailisky Alatau, Kazakstan & 0 & 0 & 4 \\
\hline M. sieversii 4 & Djungarsky Alatau, Kazakstan & 0 & 0 & 32 \\
\hline M. sieversii 5 & Djungarsky Alatau, Kazakstan & 0 & 0 & 3 \\
\hline M. sieversii 6 & Karatau, Kazakstan & 0 & 0 & 1 \\
\hline M. sieversii 7 & Khirgystan & 0 & 0 & 11 \\
\hline Species & $\begin{array}{l}\text { Malus sp. (other than } M \text {. sieversii), crab cultivars } \\
\text { (irrespective of country of origin) }\end{array}$ & 10 & 9 & 2 \\
\hline Unknown & Provenance unknown or too uncertain & 38 & 12 & 5 \\
\hline
\end{tabular}

resistance under these conditions to aid in determining if this germplasm can be enhanced for fire blight resistance via selection.

\section{Materials and Methods}

Plant material and disease evaluation. A large apple germplasm collection was assembled and established in orchards at three HortResearch sites in New Zealand (Havelock North, Riwaka, and Clyde) over the period of 1993 to 1996 (Noiton et al., 1999). The collection was divided over four sublines designated 91 to 94 , where the number denotes the year when the seeds were sown. In this study, fire blight evaluations were performed on the 92, 93, and 94 sublines at Havelock North (lat. 39 40'S, long. $176^{\circ} 53^{\prime} \mathrm{E}$ ) as the disease was present only at this site. The 92 subline consisted of 5474 trees representing 144 families ( 1 to 156 trees per family) in their $7^{\text {th }}$ leaf, most of which were derived from open-pollinated seeds from a range of Malus syvlestris var. domestica, as well as crabapples (Malus spp.) from various countries (Noiton and Shelbourne, 1992). Thirty-one families resulted from controlled crosses between apple cultivars. The 93 subline consisted of 2117 trees representing 61 families ( 1 to 101 trees per family) in their $6^{\text {th }}$ leaf, including open pollinated seeds from 57 cultivars and four species accessions. The 94 subline consisted of 1474 trees representing 70 families ( 1 to 62 trees per family) in their $5^{\text {th }}$ leaf: 52 families were derived from seeds collected from wild populations of $M$. sieversii in four regions of Kazakstan and Kyrgystan in 1993 (Hokanson et al., 1997) while18 were from open-pollinated seeds of apple cultivars.

The trees were planted at a spacing of $3 \times 0.75 \mathrm{~m}$ as single-tree plots in randomized incomplete blocks of 20 trees allocated using the 'Designer' software (K. Russell, personal communication; University of Wollongong, New South Wales, Australia). The 93 and 94 sublines were planted adjacently while the 92 subline was planted in a separate orchard approximately $8 \mathrm{~km}$ distant. The seedlings were maintained without application of copper compounds or other bactericides and under a low insecticide and fungicide program, which was ceased for the second half of the growing season (i.e., from January).

The three sublines were evaluated during the summer of 1998
99 as follows: 92 subline during 5-12 Jan. 1999; 93 subline during 9-10 Jan. 1999; and 94 subline during 16-18 Dec. 1998. We rated each tree using a scale described originally by van der Zwet et al. (1970) to estimate the severity of damage to pear (Pyrus communis L.) seedlings based on the number of branches infected, the age of the wood into which blight had penetrated, and the overall percentage of the tree blighted. However, we modified their scale by reversing the rankings such that the increments of the scale related to the percentage of the tree affected as follows: $0=0 \%$ (no disease); $1=1 \%$ to $3 \% ; 2=4 \%$ to $6 \% ; 3=7 \%$ to $12 \% ; 4=13 \%$ to $25 \% ; 5=26 \%$ to $50 \% ; 6=51 \%$ to $75 \% ; 7=76 \%$ to $88 \% ; 8=$ $89 \%$ to $99 \% ; 9=100 \%$ (tree dead). As a result, the most resistant families had the lowest values.

The date of first bloom was recorded for each tree during weekly examinations from July through Nov. 1998, and trunk girth at $30 \mathrm{~cm}$ was assessed in Apr. and May 1999. These data were used to examine whether flowering status and time, and relative tree size, were related to fire blight incidence and severity.

STATISTICAL ANALYSES. The data were first checked for spatial variation through the orchards, both trends over an entire block and localized patterns, following the same methodology used in a previous study of woolly apple aphid (Eriosoma lanigerum Hausmann) infestation in the 93 subline of this population (Alspach and Bus, 1999).

Each accession was assigned to a provenance according to its origin (Table 1) as reported in the literature (e.g., Smith, 1971), not according to the country from which the seeds were received. The provenances for $M$. sylvestris var. domestica accessions relate to some degree to the historical spread of the disease (van der Zwet and Keil, 1979). North America represents the origin of the pathogen. Fire blight was in the United Kingdom by the 1950 s, and then spread into several western and eastern European countries over the last 30 years. In addition, the $M$. sieversii seedlings from the central Asia expedition in the 94 subline were grouped according to the region from which they were collected using the region designations of Forsline (2000). Fire blight is apparently not present in central Asia and was not observed on the collection expeditions (Forsline, personal communication).

A mixed effects model was fitted to the data $y_{i j k}=\mu+P_{i}+B_{j}$ $+P_{i} / F_{k}+\varepsilon_{i j k}$, where $y_{i j k}$ was the field fire blight score for a tree 
from the $k^{\text {th }}$ family $F$ of the $i^{\text {th }}$ provenance $P$ planted in the $j^{\text {th }}$ incomplete block $B$. Provenances were modeled as fixed effects; blocks and families were taken as random. The model was fitted to each subline independently, as each consisted of a unique set of families planted in separate orchards and in successive years and, hence, was subject to different disease pressure. The full model necessarily sacrificed a considerable amount of data, since the provenance was often unknown. Thus, a reduced, random effects model was fitted, which excluded the fixed provenance effect. This reduced model was fitted to the same data as the full model for comparison.

Initial investigation confirmed that trees that had flowered had more fire blight, both in terms of incidence and severity. Furthermore, the level of fire blight was related to flowering date, with later flowering trees having higher levels. Thus, the data set was restricted to those trees that flowered in the 1998 season, and the following model was fitted $y_{j k}=\mu+f d+B_{j}+F_{k}+\varepsilon_{j k}$, where $y_{j k}$ was the field fire blight score for a tree from the $k^{\text {th }}$ family $F$ planted in the $j^{\text {th }}$ incomplete block $B$, which flowered on $f d$ day. Flowering date was a continuous variable; blocks and families were random factors. The model was fitted to each subline independently. Provenances were not included as it would have meant the sacrifice of too much data, and the previous analysis had shown this to be unnecessary.

In computing the family means, the fire blight score was first adjusted for flowering date by fitting a linear model using restricted maximum likelihood (REML) analysis. Family means were ranked, and the confidence intervals for each rank determined by bootstrapping the residuals using a modification of the method suggested by Andersson et al. (1998). The residuals from the REML analysis were resampled with replacement and added to the means to give a new data set of the same size as the original. Simple family means were then computed from this new data set, and ranked. The difference between the new rank and the original rank was calculated. The procedure was repeated 100 times. The lower bound was determined by taking the mean of those ranks lower than the original and half the exact matches; and the upper bound by averaging those ranks higher than the original and half the exact matches. Only the means of the most resistant and most susceptible families (i.e., those which ranked in the top or bottom $15 \%$ for both the upper and lower bound) have been tabulated. The family means were also used in comparing the provenances by one-way analysis of variance.

The family structure of this germplasm collection (a combination of half-and full-sib families) allowed us to estimate narrowsense heritabilities from variance components. Variance components of the models were computed using REML, and used to estimate narrow-sense heritabilities: $h^{2}=k \times s^{2} / s_{\text {total }}^{2}$, where $s_{f}^{2}$ is the variance among families (within provenances when provenance was included in the model), $\mathrm{s}_{\text {total }}$ is the total phenotypic variance, and $k$ is the coefficient of relationship (Falconer and Mackay, 1996). With $n$ pollen parents per family, $k=(0.25+0.25 /$ $n)^{-1}$, which is 2 when $n=1$ (full-sibs) and tends to 4 as $n$ tends to infinity. We have assumed an average of three pollen donors per half-sib family, and hence set $k=3$.

Distributions of the residuals from each fitted model were checked. Where these were approximately normal, the SE estimates of the heritabilities were derived from Dickerson's method for obtaining estimates of the variance of a ratio as suggested by Dieters et al. (1995). When the normality assumption was grossly inadequate, the SE estimates were obtained using the jackknife procedure (e.g., Buzas, 1997). All statistical analyses were performed using S-PLUS Ver 4.5 (MathSoft Inc., 1997).

\section{Results and Discussion}

The 1998-99 fire blight epidemic was among the most severe, uniform, and widespread observed in the Hawkes Bay region. This should have been an excellent environment for expression of the relative genetic potential of the trees in this study. The incidence of fire blight varied among the sublines. In the 92 subline, $67 \%$ of the trees exhibited symptoms of the disease, whereas the equivalent figures for the 93 and 94 sublines were $31 \%$ and $13 \%$, respectively. However, the 93 subline had the highest number of trees killed by fire blight $(2.7 \%, c f 0.1 \%$ and $0.0 \%$ for the 92 and 94 sublines, respectively). Almost half the families of the 93 subline suffered at least one tree fatality attributable to fire blight. The spatial distribution of trees with severe fire blight (i.e., score $\geq 7$ ) did not differ from a random pattern for any of the sublines. Although evidence of some minor overall spatial pattern existed, particularly for the 92 subline, the relatively small block size would prevent this from biasing the results (Alspach and Bus, 1999). The lack of any marked infection patterns in the orchards and the range in severity of symptoms suggest that natural inoculum was well dispersed and conditions for infection were favorable.

We cannot be certain whether fire blight was less prevalent in the 93 and 94 sublines due to environmental or genetic factors. If environmental factors were the cause, then the data from these two sublines, in particular, might be misleading. Infection levels may have differed due to geography as the 93 and 94 sublines were adjacent to one another but $5 \mathrm{~km}$ from the 92 subline. The 92 subline trees were older and thus larger, and likely had more flowers than trees in the 93 and 94 sublines. The greater size and flower numbers may have provided more infection sites resulting in greater disease prevalence. Alternatively, the hypothesis of environmental factors is not supported by the high incidence of extreme symptoms found in the 1993 subline, and the fact that there was no evidence of clumping in this planting.

RELATIONSHIP OF FLOWERING TO FIRE BLIGHT INFECTION. Flow-

Table 2. Proportion of trees $(\%)$ in four fire blight severity classes and corresponding score range in parentheses (from $0=$ none to $9=$ very severe, see Materials and Methods for further explanation) for each subline, divided according to whether or not the trees flowered in 1998.

\begin{tabular}{|c|c|c|c|c|c|}
\hline \multirow[b]{2}{*}{ Subline } & \multirow[b]{2}{*}{ Flowered } & \multicolumn{4}{|c|}{ Fire blight severity } \\
\hline & & None $(0)$ & Low $(1-3)$ & Medium (4-6) & $\operatorname{High}(7-9)$ \\
\hline \multirow[t]{2}{*}{$\overline{92}$} & Yes $(n=3614)$ & 23.2 & 63.9 & 12.6 & 0.3 \\
\hline & No $(\mathrm{n}=1860)$ & 52.7 & 43.7 & 3.2 & 0.4 \\
\hline \multirow[t]{2}{*}{93} & Yes $(n=1299)$ & 66.0 & 25.4 & 7.3 & 1.3 \\
\hline & No $(\mathrm{n}=818)$ & 74.4 & 15.4 & 2.3 & 7.9 \\
\hline \multirow[t]{2}{*}{94} & Yes $(n=853)$ & 82.7 & 12.8 & 4.3 & 0.2 \\
\hline & No $(n=621)$ & 92.6 & 5.4 & 1.3 & 0.7 \\
\hline
\end{tabular}


(A)

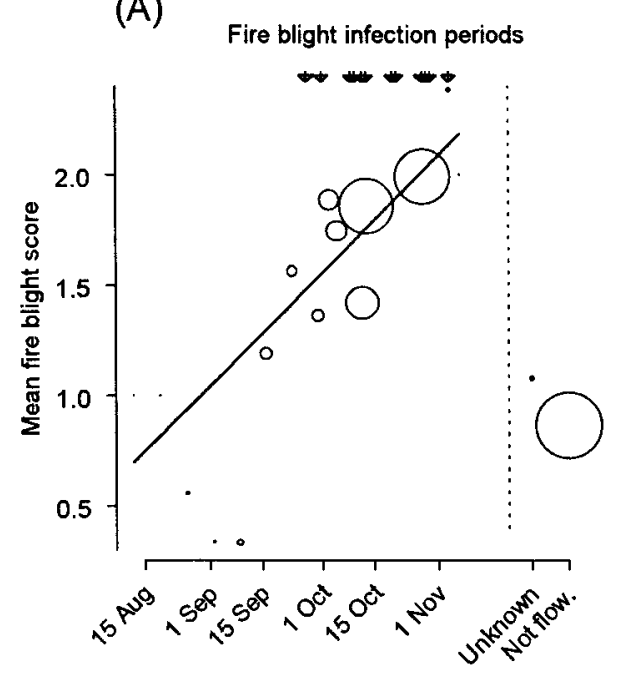

(B)

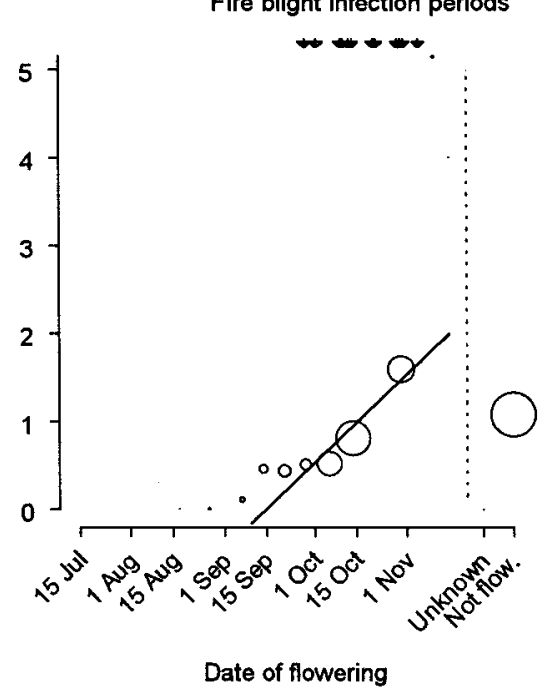

(C)

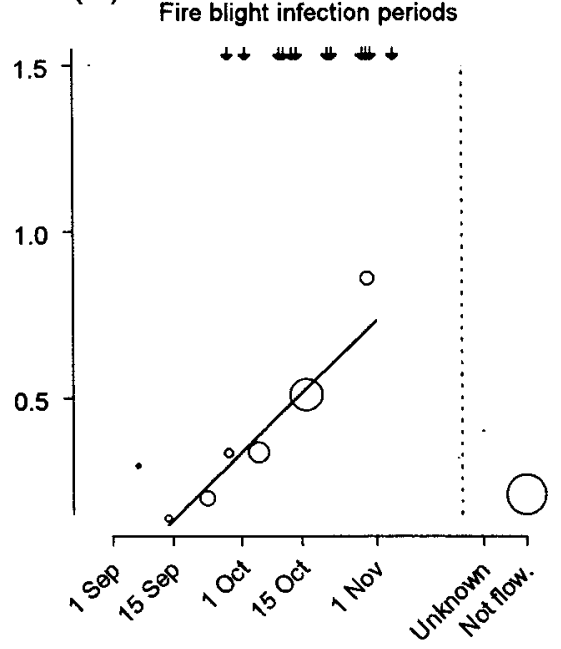

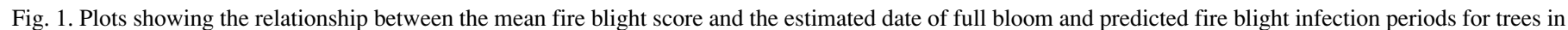
the (A) 92 subline, (B) 93 subline, and (C) 94 subline. (The area of the symbols is proportional to the number of trees.)

ering trees were more likely to be infected than nonflowering trees, in terms of both incidence and severity (Table 2, Fig. 1). Trunk girth accounted for little additional variation in fire blight score after flowering was incorporated in the model (analyses not presented). A greater proportion of the nonflowering trees escaped fire blight infection than the flowering ones. Conversely, relatively more flowering trees showed low or medium fire blight symptoms than nonflowering ones. However, a greater proportion of the nonflowering trees showed severe symptoms than flowering trees, which may reflect the relationship between girth and fire blight score. In the 92 subline, for scores $\geq 4$ (95\% of the flowering trees, and $98 \%$ of the nonflowering trees) there was a positive relationship between girth and fire blight score (analysis not presented). However, at the high levels of blight the relationship was negative. Apparently, although large trees have more entry sites for the disease, severe symptoms are most likely on small (possibly weak) trees in which a larger proportion of the tree can be affected by progression of infection from even a single site.

Relationships between flowering and fire blight infection have not been reported in apple seedlings but have been observed in pear seedlings. van der Zwet et al. (1981) reported small, but significant, correlations ( $r=0.14$ to 0.23 ) between year of first flowering and year of first blight (incidence) in five groups of same age pear seedlings, given that the level of inoculum in the orchard was reasonably high. The combined data had $r=0.38$. The percentage of seedlings which blighted during the first year of bloom was as high as $44 \%$ (in seedlings with juvenile periods of 4 or 5 years), but was lower when the juvenile periods were higher or lower. Bagnara et al. (1996) also observed that more resistant families tended to have a greater proportion of seedlings in the juvenile phase.

The fire blight score was positively correlated with the date of flowering, which was, in turn, examined in relation to predicted fire blight infection periods (Fig. 1). The fire blight infection periods were predicted using the MARYBLYT program (Gouk et al., 1996) and 1998 climate data from Pakowhai Station, Hastings (C. Gouk, personal communication), $<10 \mathrm{~km}$ from either research orchards. The first fire blight infection period was recorded 28

Table 3. Family mean and SE of fire blight scores $(0=$ none to $9=$ very severe, see Materials and Methods for further explanation $)$, considering only half-sib families, for the different provenances and Malus spp. for each subline. The analysis of the 93 subline excluded a very susceptible $M$. honanensis family.

\begin{tabular}{|c|c|c|c|c|c|c|}
\hline \multirow[b]{2}{*}{ Provenance } & \multicolumn{2}{|c|}{92 subline } & \multicolumn{2}{|c|}{93 subline } & \multicolumn{2}{|c|}{94 subline } \\
\hline & Mean & $\mathrm{SE}$ & Mean & SE & Mean & $\mathrm{SE}$ \\
\hline Species & 1.19 & 0.20 & 0.35 & 0.20 & 0.45 & 0.19 \\
\hline North America & 1.20 & 0.18 & 1.03 & 0.23 & 0.59 & 0.27 \\
\hline Western Europe & 1.53 & 0.11 & 1.05 & 0.15 & 0.37 & 0.08 \\
\hline United Kingdom & 1.33 & 0.12 & 1.03 & 0.19 & --- & --- \\
\hline Eastern Europe & 1.33 & 0.14 & 0.97 & 0.17 & --- & --- \\
\hline M. sieversii 3 & --- & --- & --- & --- & 0.14 & 0.14 \\
\hline M. sieversii 4 & --- & --- & --- & --- & 0.17 & 0.05 \\
\hline M. sieversii 5 & --- & --- & --- & --- & 0.25 & 0.16 \\
\hline M. sieversii 6 & --- & --- & --- & --- & 0.00 & 0.27 \\
\hline M. sieversii 7 & --- & --- & --- & --- & 0.38 & 0.08 \\
\hline Grand mean & 1.32 & 0.07 & 0.89 & 0.08 & 0.22 & 0.06 \\
\hline F test probability & 0.432 & & 0.058 & & 0.136 & \\
\hline Residual df & 102 & & 43 & & 57 & \\
\hline
\end{tabular}


(A)

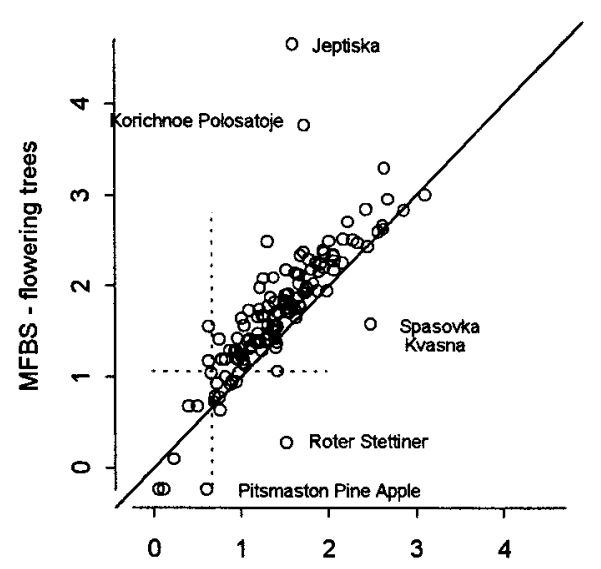

(B)

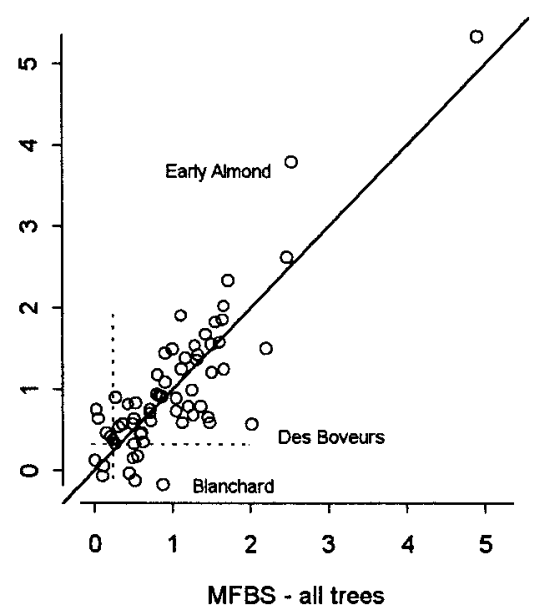

(C)

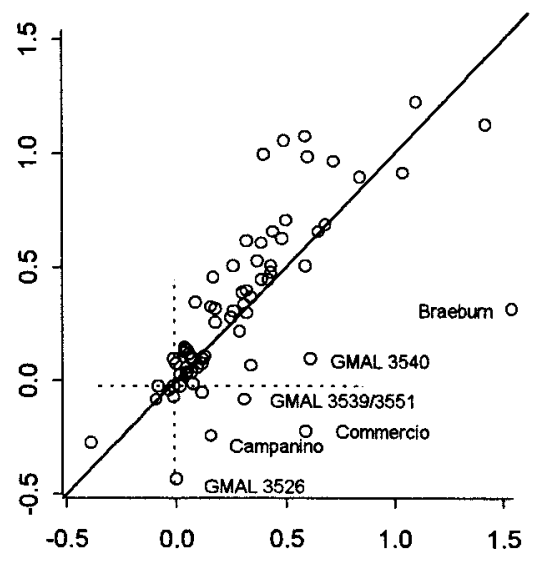

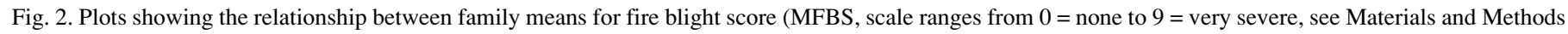
for further explanation) estimated in analyses including all trees or including only trees that flowered for the (A) 92 subline, (B) 93 subline, and (C) 94 subline.

Table 4. Number of trees, family mean score estimated by restricted maximum likelihood analysis for fire blight symptoms (rating scale from $0=$ none to $9=$ very severe, see Materials and Methods for further explanation), and rank for families in the top 15\% (most resistant families) of both the lower and upper bound of the rank, considering flowering trees only. Refer to the text for details of the computation of the bounds.

\begin{tabular}{|c|c|c|c|c|c|}
\hline $\begin{array}{l}\text { Female parent } \\
\text { (cultivar/species) }\end{array}$ & $\begin{array}{c}\text { Trees } \\
\text { (n) }\end{array}$ & $\begin{array}{c}\text { Family } \\
\text { mean score }\end{array}$ & Rank & $\begin{array}{l}\text { Lower } \\
\text { bound }\end{array}$ & $\begin{array}{l}\text { Upper } \\
\text { bound }\end{array}$ \\
\hline \multicolumn{6}{|l|}{92 subline } \\
\hline Wyken Pippin ${ }^{2}$ & 7 & -0.23 & 1 & 1 & 4 \\
\hline Pitsmaston Pine Apple & 1 & -0.23 & 2 & 1 & 22 \\
\hline Tower of Glamis ${ }^{\mathrm{z}}$ & 1 & -0.23 & 3 & 1 & 37 \\
\hline Malus toringoides ${ }^{\mathrm{z}}$ & 3 & 0.09 & 4 & 2 & 15 \\
\hline Mleenwskoje & 3 & 0.64 & 6 & 4 & 28 \\
\hline Malus baccata flexilis ${ }^{\mathrm{z}}$ & 8 & 0.68 & 7 & 5 & 17 \\
\hline Malus baccata mandshurica ${ }^{\mathrm{z}}$ & 16 & 0.68 & 8 & 6 & 15 \\
\hline Fenouillet Rouge & 43 & 0.74 & 9 & 7 & 13 \\
\hline Autumn Pearmain & 22 & 0.78 & 10 & 7 & 19 \\
\hline Fosseple $^{z}$ & 19 & 0.94 & 13 & 10 & 26 \\
\hline Nezname Stave & 9 & 0.95 & 14 & 9 & 28 \\
\hline Bespodolenoe & 14 & 0.96 & 15 & 11 & 30 \\
\hline D'Arcy Spice & 24 & 1.01 & 16 & 11 & 29 \\
\hline Hibernal $^{\mathrm{z}}$ & 5 & 1.05 & 17 & 10 & 39 \\
\hline Aromat de Vara & 27 & 1.05 & 18 & 13 & 31 \\
\hline \multicolumn{6}{|l|}{93 subline } \\
\hline Blanchard & 1 & -0.17 & 1 & 1 & 13 \\
\hline Violette $^{z}$ & 23 & -0.06 & 3 & 2 & 8 \\
\hline Fenouillet Gris & 5 & -0.03 & 4 & 2 & 18 \\
\hline Krapchatoe $1448^{z}$ & 3 & 0.06 & 5 & 2 & 19 \\
\hline London Pippin ${ }^{\mathrm{z}}$ & 30 & 0.14 & 6 & 5 & 12 \\
\hline White Paradise & 23 & 0.16 & 7 & 5 & 15 \\
\hline Northwestern Greening & 31 & 0.19 & 8 & 6 & 15 \\
\hline Rosemary Russet & 56 & 0.35 & 9 & 7 & 16 \\
\hline \multicolumn{6}{|l|}{94 subline } \\
\hline GMAL 3526 & 1 & -0.43 & 1 & 1 & 15 \\
\hline GMAL $3571^{z}$ & 1 & -0.27 & 2 & 1 & 17 \\
\hline Campanino & 6 & -0.24 & 3 & 2 & 19 \\
\hline Commercio & 10 & -0.22 & 4 & 3 & 18 \\
\hline GMAL 3539 or 3551 & 3 & -0.09 & 5 & 3 & 23 \\
\hline GMAL 3536 & 2 & -0.08 & 6 & 3 & 27 \\
\hline GMAL 3539 & 7 & -0.05 & 8 & 5 & 29 \\
\hline GMAL $3531^{z}$ & 1 & -0.02 & 10 & 5 & 29 \\
\hline
\end{tabular}

${ }^{\mathrm{z}}$ Family was also in the top $15 \%$ in the similar analysis that included all trees. 
Sept. 1998, and a further 11 were recorded before the end of flowering in early November. This, presumably, led to a build-up of inoculum over the flowering period. For this reason, the date of flowering was incorporated into the model when estimating variance components.

GERMPLASM RESPONSE FOR FIRE BLIGHT RESISTANCE. The mean family score for fire blight (considering all trees) was similar across all provenances for all sublines (Table 3). However, Malus sp. and crabapple types generally had lower values in the 92 and 93 sublines and, in the 94 subline, the central Asian M. sieversii families had a lower mean value than the $M$. sylvestris var. domestica families (Table 3). The summary for the 93 subline data (Table 3) excludes $M$. honanensis; its inclusion brings the average species score to 0.85 and increases the SEs. For the 94 subline, a contrast between the central Asian $M$. sieversii families and those from North American or western European cultivars suggested that the $M$. sieversii material may have exhibited less fire blight symptoms $\left(\mathrm{F}_{1,57}\right.$ prob.=0.053). There was little difference between the families collected from the different regions of central Asia $\left(\mathrm{F}_{4,46} P=0.155\right)$. The relatively high susceptibility of seedlings from region 7 was attributable to a single family of eight trees, six of which were uninfected while the other two were rated 4 and 7 . Exclusion of this family reduced the mean for the region from 0.38 to 0.28 and changed the $F_{4,45}$ probability to 0.437 .

Family means derived using all trees and those from only flowering trees were closely related (Fig. 2). In general, those families exhibiting a large discrepancy between the two estimates were represented by only a few trees. The families with the top and bottom combining abilities for resistance are shown in Tables 4 and 5, respectively. Among the most susceptible families (Table 5) were the $M$. honanensis accession in the 93 subline and five accessions of $M$. sieversii in the 94 subline.

Table 5. Number of trees, family mean score estimated by restricted maximum likelihood analysis for fire blight symptoms $(0=$ none to $9=$ very severe, see Materials and Methods for further explanation), and rank for families in the bottom 15\% (most susceptible families) of both the lower and upper bound of the rank considering flowering trees only. Refer to the text for details of the computation of the bounds.

\begin{tabular}{|c|c|c|c|c|c|}
\hline $\begin{array}{l}\text { Female parent } \\
\text { (cultivar/ species) }\end{array}$ & $\begin{array}{c}\text { Trees } \\
\text { (n) }\end{array}$ & $\begin{array}{c}\text { Family } \\
\text { mean score }\end{array}$ & Rank & $\begin{array}{l}\text { Lower } \\
\text { bound }\end{array}$ & $\begin{array}{l}\text { Upper } \\
\text { bound }\end{array}$ \\
\hline \multicolumn{6}{|l|}{92 subline } \\
\hline Reinette Franche & 21 & 2.39 & 118 & 104 & 124 \\
\hline Spätblühender Taffetapfel ${ }^{\mathrm{z}}$ & 20 & 2.43 & 119 & 106 & 126 \\
\hline Anurka ${ }^{\mathrm{z}}$ & 51 & 2.47 & 120 & 113 & 124 \\
\hline Aromat de Vara or Andr. Briollay & 8 & 2.48 & 121 & 104 & 128 \\
\hline M. hartwigii & 17 & 2.50 & 122 & 109 & 127 \\
\hline Fuhr $^{2}$ & 35 & 2.50 & 123 & 113 & 127 \\
\hline Hornokrajske Malinove $^{\mathrm{z}}$ & 37 & 2.51 & 124 & 117 & 127 \\
\hline Auralia $^{\mathrm{z}}$ & 49 & 2.59 & 125 & 118 & 127 \\
\hline Kitaika Solotaja Rannaja ${ }^{z}$ & 31 & 2.62 & 126 & 118 & 128 \\
\hline Uslechtile $^{\mathrm{z}}$ & 42 & 2.66 & 127 & 121 & 129 \\
\hline Paides Winter Apple ${ }^{z}$ & 5 & 2.71 & 128 & 110 & 132 \\
\hline Marie-Joseph d'Othee ${ }^{z}$ & 16 & 2.83 & 129 & 121 & 131 \\
\hline Mostove $^{\mathrm{z}}$ & 132 & 2.81 & 130 & 127 & 131 \\
\hline Octovo $^{z}$ & 24 & 2.95 & 131 & 125 & 132 \\
\hline Northwestern Greening ${ }^{z}$ & 2 & 3.00 & 132 & 108 & 134 \\
\hline Dutch Codlin ${ }^{\mathrm{z}}$ & 23 & 3.29 & 133 & 131 & 134 \\
\hline Korichnoe Polosatoje & 1 & 3.77 & 134 & 121 & 135 \\
\hline Jeptiska & 1 & 4.66 & 135 & 131 & 135 \\
\hline \multicolumn{6}{|l|}{93 subline } \\
\hline Frequin Rouge Amer & 26 & 1.80 & 57 & 54 & 59 \\
\hline Court Pendu Rose/Court Pendu Doux ${ }^{z}$ & 22 & 1.84 & 58 & 54 & 59 \\
\hline Court Pendu de France & 2 & 1.91 & 59 & 48 & 61 \\
\hline Cremiere $^{\mathrm{z}}$ & 13 & 2.01 & 60 & 56 & 61 \\
\hline Vérité $^{z}$ & 6 & 2.33 & 61 & 57 & 62 \\
\hline Edward VII ${ }^{\mathrm{z}}$ & 14 & 2.61 & 62 & 60 & 62 \\
\hline Early Almond $^{\mathrm{z}}$ & 2 & 3.79 & 63 & 62 & 63 \\
\hline M. honanensis ${ }^{\mathrm{Z}}$ & 10 & 5.30 & 64 & 64 & 64 \\
\hline \multicolumn{6}{|l|}{94 subline } \\
\hline Form $28^{z}$ & 42 & 0.87 & 62 & 58 & 65 \\
\hline Cerina $^{\mathrm{z}}$ & 37 & 0.90 & 63 & 58 & 65 \\
\hline Gelata & 27 & 0.94 & 64 & 60 & 66 \\
\hline GMAL $3554^{z}$ & 7 & 0.98 & 65 & 56 & 67 \\
\hline GMAL 3542 & 3 & 1.00 & 66 & 53 & 68 \\
\hline GMAL $3548^{z}$ & 2 & 1.06 & 67 & 52 & 69 \\
\hline GMAL 3556 & 1 & 1.08 & 68 & 55 & 69 \\
\hline GMAL $3582^{z}$ & 4 & 1.12 & 69 & 60 & 70 \\
\hline GMAL $3562^{z}$ & 42 & 1.19 & 70 & 66 & 70 \\
\hline
\end{tabular}

${ }^{\mathrm{z}}$ Family was also in the bottom $15 \%$ in the similar analysis that included all trees. 
Table 6. Narrow-sense heritability estimates and their SE values derived from fitting different models, along with the number of trees and families, for each subline. The SE estimates for the 1992 subline are derived using Dickerson's method (Dieters et al., 1995), and the others from the jackknife procedure (Buzas, 1997).

\begin{tabular}{|c|c|c|c|c|}
\hline \multirow[b]{2}{*}{ Model $^{\mathrm{z}}$} & \multicolumn{2}{|c|}{ No. } & \multirow[b]{2}{*}{ Heritability } & \multirow[b]{2}{*}{ SE } \\
\hline & Trees & $\overline{\text { Families }}$ & & \\
\hline \multicolumn{5}{|l|}{92 subline-all trees } \\
\hline$P_{i}+B_{j}+P_{i} / F_{k}$ & 3419 & 97 & 0.26 & 0.05 \\
\hline$B_{j}+F_{k}$ & 3419 & 97 & 0.27 & 0.04 \\
\hline$B_{j}^{j}+F_{k}^{k}$ & 5474 & 144 & 0.27 & 0.04 \\
\hline \multicolumn{5}{|l|}{92 subline-flowering trees } \\
\hline$B_{j}+F_{k}$ & 3614 & 135 & 0.34 & 0.05 \\
\hline$f d+B_{j}^{k}+F_{k}$ & 3614 & 135 & 0.29 & 0.06 \\
\hline \multicolumn{5}{|l|}{93 subline-all trees } \\
\hline$P_{i}+B_{j}+P_{i} / F_{k}$ & 1279 & 40 & 0.16 & 0.06 \\
\hline$B_{j}^{t}+F_{k}^{J} \quad l i k$ & 1279 & 40 & 0.14 & 0.06 \\
\hline$B_{j}^{j}+F_{k}^{k}$ & 2117 & 61 & 0.37 & 0.19 \\
\hline$\stackrel{J}{\text { excl. Malus honanensis family }}$ & 0.18 & & & \\
\hline \multicolumn{5}{|l|}{93 subline-flowering trees } \\
\hline$B_{j}+F_{k}$ & 1299 & 59 & 0.85 & 0.20 \\
\hline$f d+B_{j}+F_{k}$ & 1299 & 59 & 0.70 & 0.16 \\
\hline excl. Malus honanensis family & 0.35 & & & \\
\hline \multicolumn{5}{|l|}{94 subline - all trees } \\
\hline$P_{i}+B_{j}+P_{i} / F_{k}$ & 936 & 51 & 0.06 & 0.03 \\
\hline$B_{j}^{i}+F_{k}^{j} \quad i_{k}$ & 936 & 51 & 0.05 & 0.03 \\
\hline$B_{j}^{j}+F_{k}^{k}$ & 1474 & 70 & 0.12 & 0.04 \\
\hline \multicolumn{5}{|l|}{94 subline-flowering trees } \\
\hline$B_{j}+F_{k}$ & 853 & 65 & 0.12 & 0.05 \\
\hline$f d+B_{j}^{k}+F_{k}$ & 853 & 65 & 0.10 & 0.04 \\
\hline
\end{tabular}

"The models included the following terms: $y_{i j k}$ was the field fire blight score for a tree from the $k^{\text {th }}$ family $F$ of the $i^{\text {th }}$ provenance $P$ planted in the $j^{\text {th }}$ incomplete block $B$, which flowered on $f d$ day. See Materials and Methods for more details.

The 92 and 93 sublines were similar in that they consisted mainly of families from $M$. sylvestris var. domestica cultivars with diverse origins through North America and Europe (Table 1). The lack of consistent differences of the European and United Kingdom provenances from the North American provenance (Table 3) indicates that the North American cultivars, though potentially selected in areas where fire blight is indigenous and common, do not as a group transmit greater resistance than cultivars from the United Kingdom or mainland Europe. Likewise, the European provenances were similar to one another (Table 3). This was not surprising since most of the maternal sources are cultivars that predate the arrival and spread of fire blight in the United Kingdom and mainland Europe. Another explanation is the pathogenicity of the New Zealand E. amylovora population. Host-pathogen interaction plays an important role in evaluation of germplasm and in resistance breeding (Bell et al., 1990; Korban et al., 1988; Norelli et al, 1984, 1986;. Although it is not known how aggressive the local E. amylovora population is compared to populations in other countries, Bus and Gouk (unpublished data) have found that a host $\times$ pathogen interaction exists.

The 94 subline consisted mainly of $M$. sieversii families from central Asia. The low heritability and low infection rate may be due to smaller tree size and fewer flowers, or to lack of variation among very resistant $M$. sieversii families. Two widely planted ornamental cultivars of $M$. sieversii have been reported to be highly or very resistant (den Boer and Green, 1995). Momol et al. (1998) found that 33\% of 775 seedlings from the same 1993 collection expedition were resistant when inoculated as young seedlings, a relatively high proportion for this type of test. They observed seedlings from regions 3 and 6 were lower than those from regions 4,5 , and 7 whereas we did not detect large differences (Table 3).

The family means may be useful to a breeder choosing parents to use as sources of fire blight resistance (Table 4) or to avoid if susceptibility to the disease is a concern (Table 5). The means for families with small numbers of trees should be interpreted with caution. For example, the cultivar Northwestern Greening was reported to be resistant or moderately resistant in 13 of 15 reported studies (van der Zwet and Keil, 1979). In our study, a family from 'Northwestern Greening' with 31 flowering trees was among the most resistant in the 93 subline while another 'Northwestern Greening' family from a separate seed source with only two flowering trees was among the most susceptible in the 92 subline. Though these families were in different orchards with different overall infection levels, this apparent contradiction is most likely due to sampling of either the maternal or paternal genomes given the small size of the 92 subline family. The SE of a combining ability estimate derived from two trees will be about four times larger than a SE derived from 31 trees even assuming the two samples were drawn from the same seed source.

For most of the female parents in Tables 4 and 5 we could find no previous reports of their response to fire blight. Most are old European cultivars and many may never have been grown in areas where their fire blight response could be observed. Some of the families with Malus sp. other than M. sylvestris var. domestica as the female parents were among the more resistant families. In the 92 subline (Table 4), the family from the $M$. toringoides accession was among the more resistant, while Gardner et al. (1980a) reported that a M. toringoides accession (Has. 19) was susceptible 
when inoculated in the greenhouse. Two families of $M$. baccata were also among the most resistant in the 92 subline. In published reports, most $M$. baccata accessions have moderate to high resistance (den Boer and Green, 1995; Gardner et al., 1980a). The $M$. Xhartwiggii family in the 92 subline and the M. honanensis family in the 93 subline were among the more susceptible families (Table 5).

Several of the $M$. sieversii families that we evaluated were also evaluated by Momol et al. (1998) following inoculation of young seedlings in the greenhouse. Of the most resistant accessions in our evaluation (Table 4), GMAL 3571 and GMAL 3539 also had a high proportion of resistant seedlings in their screenings. Among the most susceptible accessions in our study (Table 5), GMAL 3562 had a high proportion of susceptible seedlings in their screenings.

Heritability of Fire blight Resistance. Heritability estimates (family mean basis) considering data from all trees were consistent across the various models within any subline (Table 6), although a single highly susceptible family inflated the estimate from the reduced model using all families from the 93 subline $(M$. honanensis open pollinated, with 33 trees). The magnitude of the heritability estimate was positively related with the level of disease present in the particular subline with the 94 subline having the lowest fire blight incidence and heritability estimates.

The heritability estimates derived from restricting the data to the flowering trees were higher than with all trees for the 92 and 93 sublines (Table 6). Furthermore, with the M. honanensis family excluded from the 93 subline, the estimates from sublines 92 and 93 were similar. The much lower value for the 94 subline could reflect the nature of the subline, i.e., high proportion of resistant families, or the fact that the natural levels of inoculum in this subline were likely to be low as it was the youngest planting and only in the first year of significant flowering. The estimates of narrow-sense heritability provide an estimate of the relative magnitude of additive genetic variance in these germplasm sets compared to the total phenotypic variance observed under the conditions of the trial. The moderate heritability estimates from the 92 and 93 sublines suggest that selection may effectively enhance these germplasm sets for fire blight resistance. In the 94 subline, selection under these conditions will be less effective, as considerably less variation was observed.

The heritability estimates for all sublines were higher if the date of flowering was excluded from the model (Table 6). Including the flowering date reduced the residual variance slightly, and the among-family variance markedly. Thus, an apparent difference between a late flowering family and an early flowering one could be reduced once flowering date was taken into account. Under conditions similar to 1998, early flowering families would be less susceptible to fire blight. Selecting for early flowering could be an indirect technique of selecting for escape from fire blight rather than resistance/tolerance per se. Thus, the estimates derived from incorporating the flowering date have greater validity.

Fire blight resistance in apple is reported to be quantitatively controlled in most studies (Korban et al., 1988) or, in resistance inherited from 'Robusta 5', involves a few genes with dominance effects (Gardner et al., 1980b). Heritability estimates have not been reported for resistance to this disease in apple. Heritabilities ranging from 0.30 to 0.61 have been reported when young pear seedlings were inoculated in the greenhouse (Quamme, 1979) or nursery (Bagnara et al., 1996). The heritabilities we estimated were generally similar to, or lower than, those reported by Bell et al. (1977) following natural infection of mature orchard-grown pear seedlings $\left(h^{2}=0.27\right.$ to 0.80$)$. They observed dramatically higher heritability values when crosses were included in the analysis which putatively segregated for a dominant gene $(\mathrm{Se})$ for sensitivity to fire blight and sudden collapse of susceptible trees (Thompson et al., 1975). This is similar to the situation we observed when the $M$. honanensis family was included in the analysis of the 93 subline. A sensitivity gene has not been reported in apple, but the response of the $M$. honanensis family in our study was similar to the response described in Pyrus (Thompson et al., 1975) suggesting that perhaps an analog of Se exists in Malus.

In conclusion, our study highlights both the opportunities and difficulties in breeding for fire blight resistance using evaluation of field infections. In several apple breeding programs, including the HortResearch program in New Zealand, greenhouse evaluations of young juvenile seedlings following inoculation are used. Greenhouse evaluations, however, are laborious and the relationship between early juvenile phase infection in a greenhouse and mature tree response may not always be consistent based on studies in pear (Quamme et al., 1990). The field environment represents the ultimate target environment in which a tree must express resistance. Our results suggest that despite the potential complications of juvenility, tree size, and flowering date in relation to infection periods, breeders should be able to exploit uniform field epiphytotics to evaluate germplasm for fire blight resistance and perform effective enhancement selection.

\section{Literature Cited}

Aldwinckle, H.S. and J.N. Cummins. 1979. Breeding apple rootstocks (Malus pumila) resistant to Erwinia amylovora. Proc. EUCARPIA Symposium on Tree Fruit Breeding, Angers, France, 3-7 Sept. 1979. p. 237-240.

Alspach, P.A. and V.G.M. Bus. 1999. Spatial variation of woolly apple aphid in a genetically diverse apple planting. N.Z. J. Ecol. 23:39-44.

Andersson, J., K. Carling, and S. Mattson. 1998. Random sampling of hospitals is unsound. Chance 11:34-39.

Bagnara, G.L., L. Rivalta, M. Laghi, and R. Quarta. 1996. Evaluation of fire blight resistance in pear: Combining ability and breeding strategy. Acta Hort. 411:383-392.

Bell, R.L., J. Janick, R.H. Zimmerman, and T. van der Zwet. 1977. Estimation of heritability and combining ability for fire blight resistance in pear. J. Amer. Soc. Hort. Sci. 102:133-138.

Bell, R.L., T. van der Zwet, W.G. Bonn, B. Thibault, and P. Lecomte. 1990 Environmental and strain effects on screening for fire blight resistance. Acta Hort. 273:343-350.

Bonn, W.G. and D.C. Elfving. 1990. Evaluation of crabapple cultivars and selections for resistance to fire blight. Acta Hort. 273:311-317.

Buzas, J.S. 1997. Fast estimators of the jackknife. Amer. Stat. 51:235240.

Currie, A.J., S. Ganeshanandam, D.A. Noiton, D. Garrick, C.J.A. Shelbourne, and N. Oraguzie. 2000. Quantitative evaluation of apple (Malus $\times$ domestica Borkh.) fruit shape by principal component analysis of Fourier descriptors. Euphytica 111:219-227.

den Boer, J.H. and T.L. Green. 1995. Crabapple disease ratings. Malus 9(2):8-58.

Dieters, M.J., T.L. White, R.C. Littell, and G.R. Hodge. 1995. Application of approximate variances of variance components and their ratios in genetic tests. Theor. Appl. Genet. 91:15-24.

Falconer, D.S. and T.F.C. Mackay. 1996. Introduction to quantitative genetics, $4^{\text {th }}$ ed. Longman, Essex, United Kingdom.

Fischer, M. 1996. Ergebnisse der Resistenzprüfungen gegenüber Erwinia amylovora (Burrill) Winslow et al. an Malus- und PyrusNachkommen im Rahmen der Unterlagenzüchtung. Erwerbsobstbau 38:77-80.

Fischer, M., C. Fischer, H-J. Schaefer, and W. Ficke. 1983b. Erste 
Ergebnisse der Resistenzzüchtung gegen Feuerbrand, Erwinia amylovora (Burrill) Winslow et al. bei Kernobst, 2. Mitt. Apfel- und Birnenunterlagen. Arch. Züchtungsforsch. 13:183-191.

Fischer, C. and H-J. Schaefer. 1990. Vergleichende Untersuchungen der Resistenz von Apfelsorten gegenüber Feuerbrand im Gewächshaus und im Freiland. Gartenbau 37:299-300.

Fischer, C., H-J. Schaefer, M. Fischer, B. Dathe, and W. Ficke. 1983a. Erste Ergebnisse der Resistenzzüchtung gegen Feuerbrand, Erwinia amylovora (Burrill) Winslow et al. bei Kernobst 1. Mitt. Apfelsorten. Arch. Züchtungsforsch. 13:137-146.

Forsline, P.L. 2000. Procedures for collection, conservation, evaluation and documentation of germplasm using Malus as an example. Acta Hort. 522:223-234

Gardner, R.G., J.N. Cummins, and H.S. Aldwinckle. 1980a. Fire blight resistance in the Geneva apple rootstock breeding program. J. Amer. Soc. Hort. Sci. 105:907-912.

Gardner, R.G., J.N. Cummins, and H.S. Aldwinckle. 1980b. Inheritance of fire blight resistance in Malus in relation to rootstock breeding. J. Amer. Soc. Hort. Sci. 105:912-916.

Gouk, S.C., R.J. Bedford, and S.O. Hutchings. 1996. Applications of the MARYBLYT computer model for identifying infection risk for fire blight of apple. Proc. 49 ${ }^{\text {th }}$ N.Z. Plant Protection Conf. 49:96-100.

Hokanson, S.C., J.R. McFerson, P.L. Forsline, W.F. Lamboy, J.J. Luby, H.S. Aldwinckle, and A.D. Djangaliev. 1997. Collecting and managing wild Malus germplasm in its center of diversity. HortScience 32:173-176.

Korban, S.S., S.M. Ries, M.J. Klopmeyer, J.F. Morrisey, and D.R. Hattermann. 1988. Genotypic responses of scab-resistant apple cultivars/selections to two strains of Erwinia amylovora and the inheritance of resistance to fire blight. Ann. Appl. Biol. 113:101-105.

Le Lezec, M., J.P. Paulin, and P. Lecomte. 1987. Shoot and blossom susceptibility to fireblight of apple cultivars. Acta Hort. 217:311-315.

Lespinasse, Y. and J.P. Paulin. 1990. Apple breeding programme for fire blight resistance: Strategy used and first results. Acta Hort. 273:285291.

MathSoft Inc. 1997. S-PLUS 4 guide to statistics. Data Anal. Products Div., MathSoft, Seattle.

Momol, M.T., P.L. Forsline, H.S. Aldwinckle, and W.F. Lamboy. 1998. Fire blight resistance and horticultural evaluation of wild Malus populations from central Asia. Acta Hort. 489:229-233.
Moore, R.C. 1946. Inheritance of fire blight resistance in progenies of crosses between several apple varieties. Proc. Amer. Soc. Hort. Sci. 47:49-57.

Noiton, D. and P. Alspach. 1996. Founding clones, inbreeding, coancestry, and status number of modern apple cultivars. J. Amer. Soc. Hort. Sci. 121:773-782.

Noiton, D., M. Hofstee, P. Alspach, L. Brewer, and C. Howard. 1999. Increasing genetic diversity for apple breeding: A preliminary report. Acta Hort. 484:105-107.

Noiton D. and C.G.A. Shelbourne. 1992. Quantitative genetics in an apple breeding strategy. Euphytica 60:213-219.

Norelli, J.L., H.S. Aldwinckle, and S.V. Beer. 1984. Differential host $\times$ pathogen interactions among cultivars of apple and strains of Erwinia amylovora. Phytopathology 74:136-139.

Norelli, J.L., H.S. Aldwinckle, and S.V. Beer. 1986. Differential susceptibility of Malus spp. cultivars Robusta 5, Novole, and Ottawa 523 to Erwinia amylovora. Plant Dis. 70:1017-1019.

Oraguzie, N.C., M. Hofstee, L. Brewer, and C. Howard. 2001. Estimation of genetic parameters in a recurrent selection program in apple. Euphytica 118:29-37.

Quamme, H.A. 1979. Heritability and effectiveness of selection for fireblight resistance in young pear seedlings inoculated in the greenhouse. Proc. EUCARPIA Fruit Section Symposium on Tree Fruit Breeding, Angers, France, 3-7 Sept. 1979. p. 73-81.

Quamme, H.A., F. Kappel, and J.W. Hall. 1990. Efficacy of early selection for fire blight resistance and the analysis of combining ability for fire blight resistance in several pear progenies. Can. J. Plant Sci. 70:905-913.

Smith, M.W.G. 1971. National apple register of the United Kingdom. Ministry of Agr., Fisheries and Food, Pinner, United Kingdom.

Thomas, T.M. and A.L. Jones. 1992. Severity of fire blight on apple cultivars and strains in Michigan. Plant Dis. 76:1049-1052.

Thompson, J.M., R.H. Zimmerman, and T. van der Zwet. 1975. Inheritance of fire blight resistance in Pyrus. J. Hered. 66:259-264.

van der Zwet, T., R.L. Bell, and R.C. Blake. 1981. Some factors affecting selection for fire blight resistance in pear. Acta Hort. 117:55-61.

van der Zwet, T. and H.L. Keil. 1979. Fire blight: A bacterial disease of rosaceous plants. Agr. Hdbk. 510. U.S. Dept. Agr., Wash. D.C.

van der Zwet, T., W.A. Oitto, and H.J. Brooks. 1970. Scoring system for rating the severity of fire blight in pear. Plant Dis. Rptr. 54:835-839. 